\title{
PENGEMBANGAN PEMANFAATAN MEDIA PEMBELAJARAN GEOGRAFI BERBASIS PREZI PADA MATERI DINAMIKA ATMOSFER DAN DAMPAKNYA TERHADAP KEHIDUPAN
}

\author{
Nilam Sari \\ Pendidikan Geografi \\ Fakultas Ilmu Sosial \\ Universitas Negeri Padang \\ nilamsari3995@gmail.com
}

\begin{abstract}
Abstrak
Penelitian ini bertujuan untuk menghasilkan produk media pembelajaran geografi berbasis prezi pada materi dinamika atmosfer dan dampaknya terhadap kehidupan yang valid dan praktis digunakan dalam kegiatan pembelajaran. Jenis penelitian ini termasuk penelitian Research and Development dengan menggunakan model 4-D). Model ini dikembangkan dalam empat tahap yaitu pendefinisian (define), perancangan (design), pengembangan (develop), dan penyebaran (disseminate). Dari hasil penelitian dapat disimpulkan bahwa media pembelajaran geografi berbasis prezi berada pada kategori valid dari ahli materi dengan nilai $89,425 \%$, kategori sangat valid dari ahli media dengan nilai 91,44\%, kategori praktis dari guru geografi SMA 8 Padang dengan nilai $88,46 \%$ dan kategori praktis dari siswa dengan nilai $82,34 \%$.
\end{abstract}

\section{Kata Kunci: Media Pembelajaran Geografi, Media Prezi, Model 4-D}

\begin{abstract}
This study aims to produce prezi-based teaching materials on atmospheric dynamics materials and their impact on a valid and practical life used in learning activities. This type of research includes Research and Development research using 4-D model. This model was developed in four stages of definition, define, development, and disseminate. From the research result, it can be concluded that the prezi-based teaching materials are in valid category from material experts with the value of $89,425 \%$, very valid category from media expert with 91,44\% value, practical category from SMA 8 Padang geography teacher with $88,46 \%$ and the practical category of students with a value of $82.34 \%$.
\end{abstract}

Keyword: Geography Learning Media, Prezi Media, 4-D model

\section{PENDAHULUAN}

Sampai saat ini pembelajaran Geografi di SMA masih diliputi oleh berbagai permasalahan baik yang terkait dengan rendahnya kualitas aktivitas belajar siswa, guru yang masih mendominasi pembelajaran serta soal dan tugas yang belum mewadahi pengembangan kemampuan berfikir tingkat tinggi serta siswa cenderung pasif dan masih ditempatkan sebagai penerima materi semata (Nofrion, 2017:11-12). Jika dalam pembelajaran, aktivitas belajar masih dalam koridor aktivitas belajar dasar seperti mengamati, menanya, mencoba dan mengumpulkan, hal ini akan menyulitkan tercapainya pengembangan keterampilan berfikir tingkat tinggi bagi siswa (Nofrion, 2018;2).

Salah satu upaya untuk mengatasi hal tersebut adalah dengan meningkatkan keterlibatan siswa dalam pembelajaran melalui pemanfaatan media pembelajaran yang menarik. Dari sekian banyak media 
pembelajaran, media proyeksi berbasis prezi memiliki keunggulan dibanding media sejenisnya. Media presi mampu menyajikan tampilan bahan presentasi pembelajaran dengan lebih menarik, variatif dan memiliki fitur-fitur unggul seperti zoom in dan zoom out yang memungkinkan bisa melihat sesuatu dengan lebih detail dan jelas dalam satu slide saja.

Atas dasar itulah peneliti tertarik mengembangkan media pembelajaran geografi menggunakan prezi dengan judul "Pengembangan Pemanfaatan Media pembelajaran geografi Berbasis Prezi Pada Materi Dinamika Atmosfer dan Dampaknya Terhadap Kehidupan”.

\section{METODE PENELITIAN}

Jenis penelitian yang digunakan dalam penelitian ini adalah penelitian pengembangan atau Research and Development. Penelitian ini sesuai dengan level Kerangka Kualifikasi Nasional Indonesia (KKNI) maka pengembangan yang dilakukan dibatasi pada level S1 yaitu pada level 6 KKNI yaitu mengaplikasikan, mengkaji, membuat desain, memanfaatkan IPTEK, dan menyelesaikan masalah. Dalam Setyosari (2010:193) "penelitian pengembangan adalah suatu proses yang dipakai untuk mengembangkan dan memvalidasi produk penelitian". Menurut Nusa Putra (2011: 67) secara sederhana R \& D bisa didefinisikan sebagai metode penelitian yang secara sengaja, sistematis, bertujuan/diarahkan untuk mencaritemukan, merumuskan, memperbaiki, mengembangkan, menghasilkan, menguji keefektifan produk, mode, metode/strategi/cara, jasa, prosedur tertentu yang lebih unggul, baru, efektif, efisien, produktif dan bermakna.

Objek penelitian Objek penelitian ini ada dua hal yang menjadi objek penelitian pertama adalah media pembelajaran geografi berbasis prezi. Media pembelajaran geografi berbasis prezi yang dikembangkan ini berisi materi geografi SMA untuk kelas $\mathrm{X}$ pada semester 2 tentang dinamika atmosfer dan dampaknya terhadap kehidupan. Objek kedua adalah siswa kelas X siswa yang menjadi objek penelitian adalah satu kelas dari total Sembilan kelas yang ada di SMA Negeri 8 Padang dengan jumlah siswa sebanyak 30 orang. Teknik pengambilan sampel dalam penelitian ini menggunakan teknik simple random sampling. Dalam Sugiono (2009:120) dikatakan simple (sederhana) karena pengambilan anggota sampel dari populasi dilakukan secara acak tanpa memperhatikan strata yang ada dalam populasi itu.

Media pembelajaran geografi berbasis prezi yang dikembangkan dengan menggunakan model 4-D yaitu melalui tahap define (pendefinisian), design (perancangan), develop (pengembangan), dan disseminate (penyebaran) sebagaimana yang disarankan Thiagarajan dan Semmel 1974 dalam Trianto (2010:189). Tahap pertama yaitu define (pendefinisian) dengan langkah-langkahnya yaitu analisis awal akhir, analisis siswa dan analisis materi, tahap kedua yaitu design 
(perancangan) dengan langkah-langkah yaitu Penyusunan materi dan Perancangan awal, tahap ketiga yaitu develop (pengembangan) dengan langkah-langkahnya Validasi oleh validator, Revisi 1, Ujicoba, Analisis hasil ujicoba, dan tahap keempat yaitu disseminate (penyebaran).

Instrumen yang digunakan untuk mengumpulkan data terdiri dari 4 bagian yaitu: lembar intrumen validitas media pembelajaran geografi dari ahli materi dan dari ahli media, angket uji kepraktisan dari guru dan siswa tentang keterlaksanaan penerapan media pembelajaran geografi berbasis prezi pada materi dinamika atmosfer dan dampaknya terhadap kehidupan.

Analisis data dilakukan setelah didapatkan data dari lembaran angket validasi dan lembaran angket kepraktisan, Teknik analisis data yang digunakan dalam penelitian ini adalah:

\section{1) Teknik Analisis Validitas Produk}

Validitas adalah suatu konsep yang berkaitan dengan sejauh mana tes telah mengukur apa yang seharusnya diukur, Supranata dalam Andi Putra Sairi (2011: 39-40). Sebuah tes dikatakan valid apabila dapat mengukur apa yang diinginkan atau dapat mengungkap data dari variabel yang diteliti secara tepat, tinggi rendahnya validitas tes menunjukkan sejauh mana data yang terkumpul tidak menyimpang dari gambaran tentang validitas yang dimaksud, Andi Putra Sairi (2011: 39-40).

Penilaian produk berdasarkan angket yang telah diisi oleh tenaga ahli dan praktisi dianalisis untuk mengetahui tingkat kevalidan dari produk yang dikembangkan. Analisis validitas menggunakan Skala Likert oleh Pohan dalam Ika Anggraini (2011:33-34) dengan alternative jawaban sebagai berikut:

SS = sangat setuju dengan bobot 4

$\mathrm{S}$ = setuju dengan bobot 3

$\mathrm{TS}=$ Tidak setuju dengan bobot 2

STS =sangat tidak setuju dengan bobot1

Analisis validitas media pembelajaran berdasarkan lembar validasi dilakukan dengan beberapa langkah yaitu:

a) Memberi skor jawaban dengan kriteria berdasarkan skala likert seperti modivikasi dari Purwanto (2009 : 81) sebagai berikut:

Skor 4 untuk jawaban sangat setuju

Skor 3 untuk jawaban setuju

Skor 2 untuk jawaban tidak setuju

Skor 1 untuk jawaban sangat tidak setuju

b) Menentukan skor tertinggi dengan cara:

(Banyak validator) $\mathrm{x}$ (banyak indikator) $\mathrm{x}$ skor maksimum)

c) Menentukan skor yang diperoleh dengan cara menjumlahkan skor masing-masing validator.

d) Memberikan nilai validitas dengan cara:

$$
P=\frac{f}{n \times 100 \%}
$$

Keterangan:

$\mathrm{P}=$ Nilai akhir

$f=$ Perolehan skor

$\mathrm{n}=$ Skor maksimum 
e) Memberi penilaian validitas dengan kriteria seperti yang dikemukakan Purwanto (2009 : 82)

Tabel 1. Kriteria Penilaian Validitas

\begin{tabular}{|l|l|l|}
\hline No & \multicolumn{1}{|c|}{ Nilai } & \multicolumn{1}{c|}{ Kriteria } \\
\hline 1 & $90 \%-100 \%$ & Sangat valid \\
\hline 2 & $80 \%-89 \%$ & Valid \\
\hline 3 & $65 \%-79 \%$ & Cukup valid \\
\hline 4 & $55 \%-64 \%$ & Kurang valid \\
\hline 5 & $<55 \quad \%$ & Tidak valid \\
\hline
\end{tabular}

Sumber: Purwanto 2009

\section{2) Teknik Analisis Kepraktisan}

Suatu produk/sumber belajar dikatakan praktis jika siswa dapat menggunakan media pembelajaran geografi berbasis prezi dalam pembelajaran secara praktis dan efisien.Kepraktisan produk dianalisis berdasarkan angket yang telah diisi oleh siswa. Analisis data angket kepraktisan media pembelajaran geografi berbasis prezi dalam pembelajaran Geografi berdasarkan angket siswa dengan langkah-langkah berikut ini:

a) Memberikan skor jawaban dengan kriteria sebagai berikut:

STS = sangat tidak setuju dengan bobot 1

TS = tidak setuju dengan bobot 2

$\mathrm{S}=$ Setuju dengan bobot 3

$\mathrm{SS}=$ sangat setuju dengan bobot 4

b) Menentukan skor rata-rata dengan cara

Jumlah nilai yang didapat $\div$ banyaknya indikator

c) Skor maksimum pada uji kepraktisan ini adalah 4

d) Pemberian nilai kepraktisan dengan cara:

$$
P=\frac{f}{n} \times 100 \%
$$

Keterangan:

$\mathrm{P}=$ Nilai akhir

$f=$ Perolehan skor

$\mathrm{n}=$ Skor maksimum

e) Setelah persentase nilai kepraktisan diperoleh, dilakukan pengelompokan sesuai kriteria yang dimodifikasi dari Purwanto (2009 : 102-103).

Tabel 2. Kriteria Penilaian Kepraktisan

\begin{tabular}{|l|l|l|}
\hline No & Nilai & Kriteria \\
\hline 1 & $90 \%-100 \%$ & Sangat praktis \\
\hline 2 & $80 \%-89 \%$ & praktis \\
\hline 3 & $65 \%-79 \%$ & Cukup praktis \\
\hline 4 & $55 \%-64 \%$ & Kurang praktis \\
\hline 5 & $<55 \quad \%$ & Tidak praktis \\
\hline
\end{tabular}

Sumber: Dimodifikasi dari Purwanto 2009

\section{HASIL DAN PEMBAHASAN}

\section{a. Tahap Define (Pendefinisian)}

1) Analisis Awal Akhir

Analisis yang penulis lakukan dengan guru mata pelajaran geografi didapat gambaran bahwa proses pembelajaran geografi di sekolah masih didominasi oleh metode yang konvensional seperti metode ceramah yang membuat pembelajaran menjadi tidak menarik. Media yang digunakan oleh guru masih kurang menarik perhatian siswa dalam belajar, respon siswa masih rendah terhadap materi pelajaran sehingga kurangnya umpan balik dari siswa, dengan tidak adanya umpan balik dari siswa menjadikan komunikasi bersifat hanya satu arah. Beberapa materi geografi pada kelas X bersifat abstak dan sulit untuk 
divisualisasikan khususnya pada materi dinamika atmosfer dan dampaknya terhadap kehidupan.

2) Analisis Siswa

Analisis siswa dilakukan untuk mengetahui bagaimana karakteristik siswa SMA Negeri 8 Padang dari analisis yang penulis lakukan didapat beberapa karakteristik siswa yaitu sebagai berikut:

a) Siswa kelas $X$ rata-rata berjumlah 30 orangdengan usia rata-rata $15-16$ tahun.

b) Beberapa materi pada kelas xada yang bersifat abstrak dan sulit divisualisasikan seperti materi dinamika atmosfer dan dampaknya terhadap kehidupan, perlu ada pengembangan media pembelajaran geografi yang bisa mendukung untuk materi ini.

c) Penelitian dilakukan khususnya pada kelas X IPS SI BIO 2 dengan jumlah siswa 30 orang.

d) Siswa bersifat sangat terbuka dengan perkembangan ilmu pengetahuan dan teknologi (IPTEK)

3) Analisis Materi

Dalam pelaksanaan pembelajaran SMAN 8 Padang melaksanakan kurikulum 2013 yang mengacu pada Permendikud no.21 tahun 2016 tentang standar isi pendidikan dasar dan menengah yang memuat tentang tingkat kompetensi dan kompetensi inti sesuai dengan jenjang dan jenis pendidikan tertentu. Kompetensi inti meliputi sikap spiritual, sikap sosial, pengetahuan dan keterampilan. Ruang lingkup materi yang spesifik untuk semua mata pelajaran dirumuskan berdasarkan tingkat kompetensi dan kompetensi inti untuk mencapai kompetensi lulusan minimal pada jenjang dan jenis pendidikan tertentu. Mata pelajaran geografi merupakan salah satu mata pelajaran yang menggunakan kurikulum acuan standar isi. Berikut ini adalah tabel penjabaran standar KI dan KD pelajaran geografi kelas $\mathrm{X}$ berdasarkan standar isi. Silabus yang dipakai adalah silabus kurikulum 2013.

Analisis materi dilakukan berdasarkan wawancara dan observasi, didapat gambaran bahwa pada kompetensi inti dan kompetensi dasar pada materi dinamika atmosfer dan dampaknya terhadap kehidupan merupakan pokok bahasan dengan materi yang sifatnya abstrak serta sulit untuk divisualisasikan dan sulit dipahami oleh siswa sehingga kurangnya minat siswa pada pelajaran geografi khususnya pada materi dinamika atmosfer dan dampaknya terhadap kehidupan. KD 3.6 ini terdiri dari beberapa indikator.

\section{b. Tahap Design (Perancangan)}

1) Penyusunan Materi

a) Menentukan dan memahami KI dan KD dinamika atmosfer dan dampaknya terhadap kehidupan.

b) Menentukan indikator yang mendukung dari KD.

c) Menentukan tujuan pembelajaran yang mendukung dari indikator. 
d) Menentukan materi yang akan digunakan pada aplikasi prezi sebagai media pembelajaran.

e) Merancang peta konsep yang menghubungkan materi dalam materi dinamika atmosfer dan dampaknya terhadap kehidupan

f) Membuat uraian materi yang terdapat dalam pokok bahasan dinamika atmosfer dan dampaknya terhadap kehidupan.

(1) Karakteristik lapisan-lapisan atmosfer bumi.

(2) Pengukuran unsur-unsur cuaca dan interpretasi data cuaca.

(3) Klasifikasi tipe iklim dan pola iklim global.

(4) Karakteristik iklim di Indonesia dan pengaruhnya terhadap aktifitas manusia

(5) Pengaruh perubahan iklim global terhadap kehidupan.

(6) Lembaga-lembaga yang menyediakan dan memanfaatkan data cuaca dan iklim di Indonesia.

g) Mencari gambar serta video yang sesuai dengan submateri serta untuk mendukung materi dinamika atmosfer dan dampaknya terhadap kehidupan.

h) Mencari nilai religi yang sesuai dengan materi dinamika atmosfer dan dampaknya terhadap kehidupan untuk mendukung materi.

i) Membuat soal-soal latihan yang berhubungan dengan materi pada setiap pertemuan.

2) Perancangan Awal
Setelah penyusunan konsep materi pelajaran pokok bahasan dinamika atmosfer dan dampaknya terhadap kehidupan ditentukan. Maka dilakukan proses perancangan media pembelajaran geografi. Proses perancangan ini dilakukan dengan menentukan tampilan, bentuk, warna dan urutan yang akan ditampilkan mulai dari apersepsi, KI dan KD, indikator, tujuan pembelajaran, dan sub materi, gambar, video, unsur religi, dan soal-soal. Setelah rancangan media pembelajaran geografi selesai dibuat, maka langkah selanjutnya adalah membuat media pembelajaran geografi tersebut menggunakan aplikasi prezi.

\section{c. Tahap Develop (Pengembangan)}

Pada tahap develop ini hasil yang diperoleh dari penelitian ini terdiri atas 6 tahap. Keenam tahap ini meliputi: hasil validasi media pembelajaran geografi berbasis prezi oleh ahli materi, hasil revisi media pembelajaran geografi berbasis prezi dari ahli materi, hasil validasi media pembelajaran geografi geografi berbasis prezi oleh ahli media, hasil revisi media pembelajaran geografi berbasis prezi dari ahli media, hasil uji kepraktisan terhadap media pembelajaran geografi berbasis prezi oleh guru dan hasil uji kepraktisan oleh siswa. Hasil revisi media pembelajaran geografi geografi dilakukan dengan mempertimbangkan berbagai saran dan masukan dari ahli materi, ahli media dan praktikalis dari guru dan siswa terhadap keterbatasan, kekurangan serta kesalahan yang 
terdapat dalam media pembelajaran geografi berbasis prezi.

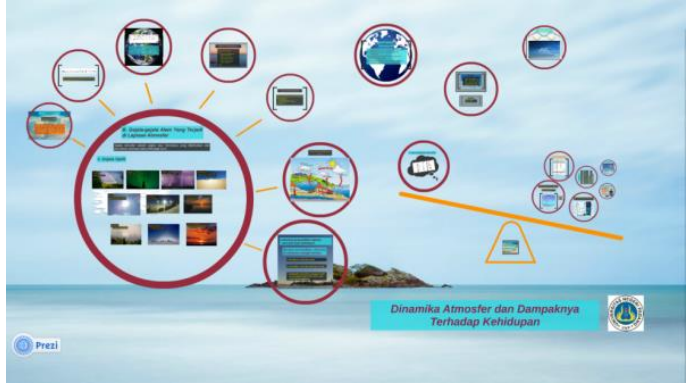

Gambar 1. Hasil akhir produk untuk pertemuan 1

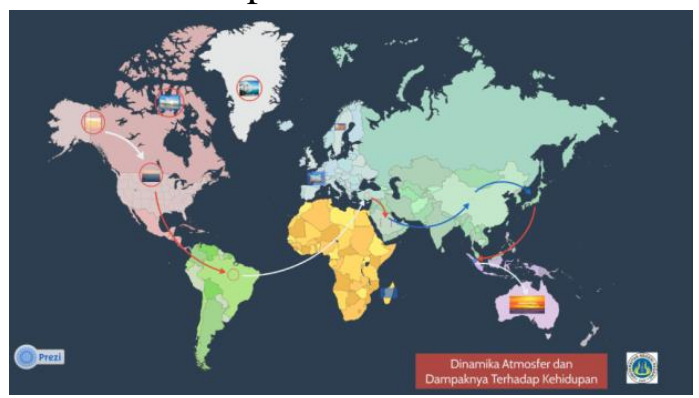

Gambar 2. Hasil akhir produk untuk prtemuan 2

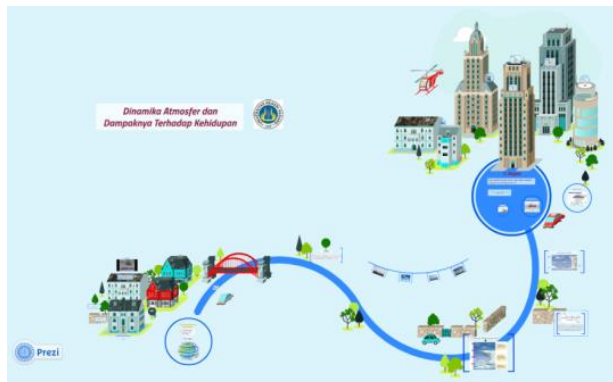

Gambar 3. Hasil akhir produk untuk pertemuan 3

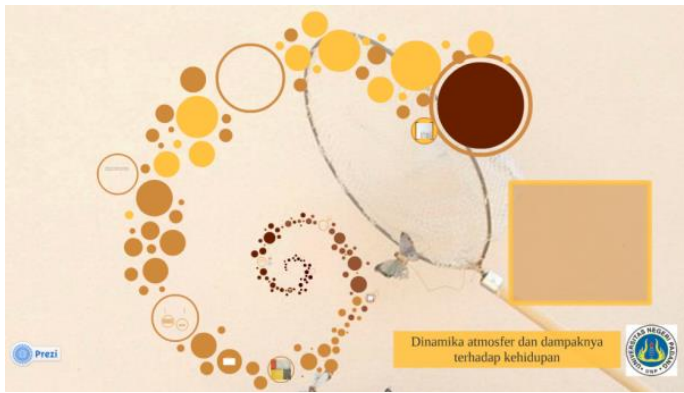

Gambar 4. Hasil akhir produk untuk pertemuan 4

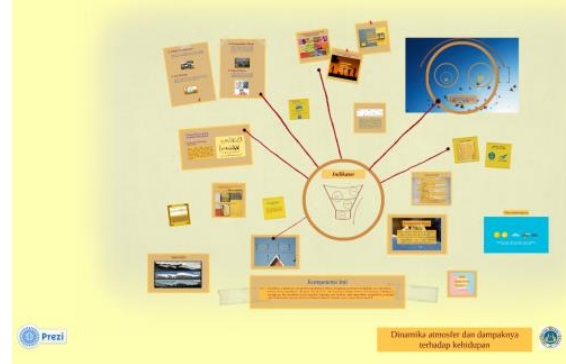

Gambar 5. Hasil akhir produk untuk pertemuan 5

\section{Hasil Akhir Validitas}

a. Hasil validitas ahli materi

Komponen validitas yang dinilai oleh ahli materi terdapat empat komponen yaitu: 1) isi/materi, 2) kebahasaan, 3) penyajian, 4) kegrafisan. Deskripsi hasil penilaian validitas pada empat komponen tersebut dapat dilihat pada tabel 3

Tabel 31. Rata-rata Hasil Setiap Komponen

\begin{tabular}{|l|l|l|l|}
\hline No & Pernyataan & \multicolumn{1}{|c|}{$\begin{array}{c}\text { Nilai } \\
\text { Total }\end{array}$} & Kriteria \\
\hline 1 & Isi/materi & $90 \%$ & $\begin{array}{l}\text { Sangat } \\
\text { valid }\end{array}$ \\
\hline 2 & kebahasaan & $89,6 \%$ & valid \\
\hline 3 & penyajian & $90,6 \%$ & valid \\
\hline 4 & kegrafisan & $87,5 \%$ & valid \\
\hline & jumlah & $357,7 \%$ & \\
\hline & Total akhir & $\mathbf{8 9 , 4 2 5 \%}$ & valid \\
\hline
\end{tabular}

Sumber : Olahan Data primer 2017

Tabel 3 menunjukkan nilai validasi pada instrument yang diisi oleh ahli materi terdiri dari empat komponen yaitu isi/materi, kebahasaan, penyajian, kegrafisan berkisar antara 87,5\% sampai 90,6\%. Nilai terendah berada pada komponen kegrafisan dengan nilai $87,5 \%$. Nilai tertinggi berada pada komponen penyajian dengan nilai 90,6\%. Sedangkan pada komponen isi/materi mendapat nilai $90 \%$ dan pada komponen kebahasaan mendapat nilai 
$89,6 \%$. Nilai rata-rata instrument ahli materi adalah $89,425 \%$. Nilai validitas oleh ahli materi untuk keempat komponen berada pada kategori valid.

b. Hasil validitas media

Komponen validitas yang dinilai oleh ahli media terdapat tiga komponen yaitu: 1) aspek efisiensi, 2) Aspek tampilan program, 3) Aspek kualitas teknis dan keefektifan program. Deskripsi hasil penilaian validitas pada tiga komponen tersebut dapat dilihat pada tabel 4.

Tabel 4. Rata-rata Hasil Setiap Komponen

\begin{tabular}{|l|l|l|l|}
\hline No & Pernyataan & Nilai & Kriteria \\
\hline 1 & aspek efisiensi & $93,7 \%$ & $\begin{array}{l}\text { Sangat } \\
\text { valid }\end{array}$ \\
\hline 2 & $\begin{array}{l}\text { Aspek } \\
\text { tampilan } \\
\text { program }\end{array}$ & $\begin{array}{l}90 \% \\
\text { teknis dan } \\
\text { keefektifan } \\
\text { program }\end{array}$ & valid \\
\hline & Jumlah & 274,32 & $\begin{array}{l}\text { Sangat } \\
\text { valid }\end{array}$ \\
\hline & $\begin{array}{l}\text { Total Akhir } \\
\mathbf{9 1 , 4 4 \%}\end{array}$ & $\begin{array}{l}\text { Sangat } \\
\text { valid }\end{array}$ \\
\hline
\end{tabular}

Sumber: Olahan Data Primer 2017

Tabel 4 menunjukkan nilai validasi pada instrument yang diisi oleh ahli media terdiri dari tiga komponen yaitu aspek efisiensi, Aspek tampilan program, dan Aspek kualitas teknis dan keefektifan program berkisar antara 90\% sampai 93,7\%. Nilai terendah berada pada komponen aspek tampilan program dengan nilai 90\%. Nilai tertinggi berada pada komponen aspek efisiensi dengan nilai 93,7\%. Sedangkan pada komponen Aspek kualitas teknis dan keefektifan program mendapat nilai
90,62\% Nilai rata-rata instrument ahli media adalah 91,44\%. Nilai validitas oleh ahli media untuk ketiga komponen berada pada kategori sangat valid.

a. Hasil kepraktisan oleh Guru

Komponen kepraktisan yang dinilai oleh praktisi terdapat empat komponen yaitu: 1) minat siswa dan tampilan media pembelajaran geografi,

2) proses penggunaan, 3) pemahaman konsep dan materi, 4) waktu. Deskripsi hasil penilaian kepraktisan pada empat komponen tersebut dapat dilihat pada tabel 5.

Tabel5. Rata-rata Hasil Setiap Komponen

\begin{tabular}{|l|l|l|l|}
\hline No & Pernyataan & Nilai & Kriteria \\
\hline 1 & $\begin{array}{l}\text { minat siswa } \\
\text { dan media } \\
\text { pembelajaran } \\
\text { geografi }\end{array}$ & $87,5 \%$ & praktis \\
\hline 2 & $\begin{array}{l}\text { proses } \\
\text { penggunaan }\end{array}$ & $89,3 \%$ & praktis \\
\hline 3 & $\begin{array}{l}\text { pemahaman } \\
\text { konsep dan } \\
\text { materi }\end{array}$ & $83,3 \%$ & praktis \\
\hline 4 & $\begin{array}{l}\text { waktu } \\
93,75 \%\end{array}$ & $\begin{array}{l}\text { Sangat } \\
\text { praktis }\end{array}$ \\
\hline & Jumlah & $\mathbf{3 5 3 , 8 5}$ & praktis \\
\hline & Total Akhir & $\mathbf{8 8 , 4 6 \%}$ & Prah \\
\hline
\end{tabular}

Sumber: Olahan Data Primer 2017

Tabel 5 menunjukkan nilai kepraktisan pada instrumen yang diisi oleh praktisi terdiri dari empat komponen yaitu minat siswa dan tampilan media pembelajaran geografi, proses penggunaan, pemahaman konsep dan materi, waktu berkisar antara 83,3\% sampai $93,75 \%$. Nilai terendah berada pada komponen pemahaman konsep dan materi dengan nilai $83,3 \%$. Nilai 
tertinggi berada pada komponen waktu dengan nilai $93,75 \%$. Sedangkan pada komponen minat siswa dan media pembelajaran geografi mendapat nilai $87,5 \%$ dan pada komponen proses penggunaan mendapat nilai $89,3 \%$. Nilai rata-rata instrument praktikalis guru adalah 88,46\%. Nilai kepraktisan oleh praktisi untuk keempat komponen berada pada kategori praktis.

b. Hasil Siswa

Komponen kepraktisan yang dinilai oleh siswa terdapat empat komponen yaitu: 1) minat siswa dan tampilan media pembelajaran geografi, 2) proses penggunaan, 3) pemahaman konsep dan materi, 4) waktu. Deskripsi hasil penilaian kepraktisan pada empat komponen tersebut dapat dilihat pada tabel 6.

Tabel 6. Rata-rata Hasil Setiap Komponen

\begin{tabular}{|c|c|c|c|}
\hline No & Pernyataan & Nilai & Kriteria \\
\hline 1 & $\begin{array}{l}\text { Minat siswa } \\
\text { dan tampilan } \\
\text { media } \\
\text { pembelajaran } \\
\text { geografi }\end{array}$ & $83,46 \%$ & Praktis \\
\hline 2 & $\begin{array}{l}\text { Proses } \\
\text { penggunaan }\end{array}$ & $80,45 \%$ & Praktis \\
\hline 3 & $\begin{array}{l}\text { Pemahaman } \\
\text { konsep dan } \\
\text { materi }\end{array}$ & $81,25 \%$ & Praktis \\
\hline \multirow[t]{3}{*}{4} & Waktu & $84,2 \%$ & Praktis \\
\hline & Jumlah & 329,36 & \\
\hline & Total Akhir & $82,34 \%$ & Praktis \\
\hline
\end{tabular}

Sumber: Olahan Data Primer 2017

Tabel 6 menunjukkan nilai kepraktisan pada instrument yang diisi oleh siswa terdiri dari empat komponen yaitu Minat siswa dan tampilan media pembelajaran geografi, Proses penggunaan, Pemahaman konsep dan materi, waktu berkisar antara 80,45\% sampai $84,2 \%$. Nilai terendah berada pada komponen Proses penggunaan dengan nilai $80,45 \%$. Nilai tertinggi berada pada komponen waktu dengan nilai $84,2 \%$. Sedangkan nilai komponen minat dan tampilan media pembelajaran geografi mendapat nilai $83,46 \%$ dan pada komponen pemahaman konsep dan materi mendapat nilai $81,25 \%$. Nilai rata-rata praktikalis oleh praktisi adalah $82,34 \%$. Nilaikepraktisan oleh siswa untuk keempat komponen berada pada kategori praktis.

Berdasarkan penelitian yang dilakukan maka diperoleh hasil penelitian, keterbatasan, kelemahan dan kekurangan serta solusi untuk mengatasi semua keterbatasan serta kekurangan yang ada pada media pembelajaran geografi berbasis prezi pada materi dinamika atmosfer dan dampaknya terhadap kehidupan. Hasil penelitian yang telah dilakukan, maka diperoleh hasil berupa proses dari pengembangan model 4-D, validitas media pembelajaran geografi berbasis prezi, kepraktisan media pembelajaran geografi berbasis prezi. Hasil penelitian ini meliputi hasil validasi media pembelajaran geografi berbasis prezi oleh ahli materi, hasil revisi media pembelajaran geografi berbasis prezi dari ahli materi, hasil validasi media pembelajaran geografi geografi berbasis prezi oleh ahli media, hasil revisi media pembelajaran geografi berbasis prezi dari ahli media, hasil uji kepraktisan 
terhadap media pembelajaran geografi geografi oleh guru dan siswa sebagai penggunaan media pembelajaran geografi berbasis prezi pada materi dinamika atmosfer dan dampaknya terhadap kehidupan.

Hasil penelitian dan pengembangan ini berupa produk media pembelajaran geografi berbasis prezi pada materi dinamika atmosfer dan dampaknya terhadap kehidupan. Penelitian ini mengacu pada tahapan penelitian model 4-D. Proses pengembangan model 4-D ini terdiri dari tahap pertama yaitu tahap define (pendefinisian), yaitu melakukan 1) analisis awal akhir ditemukan beberapa hal yaitu Media yang digunakan oleh guru masih kurang menarik perhatian siswa dalam belajar, respon siswa masih rendah terhadap materi pelajaran sehingga kurangnya umpan balik dari siswa, dengan tidak adanya umpan balik dari siswa menjadikan komunikasi bersifat hanya satu arah. Beberapa materi sulit untuk divisualisasikan seperti materi dinamika atmosfer dan dampaknya terhadap kehidupan. Selanjutnya 2) analisis siswa ditemukan beberapa hal yaitu siswa berumur 15-16 orang, kurangnya inovasi guru menggunakan media yang bisa menarik perhatian siswa, siswa bersifat terbuka dengan ilmu pengetahuan dan teknologi. Selanjunya 3) analisis materi ditemukan yaitu pokok bahasan dengan materi yang sifatnya abstrak serta sulit untuk divisualisasikan dan sulit dipahami oleh siswa sehingga kurangnya minat siswa pada pelajaran geografi khususnya pada materi dinamika atmosfer dan dampaknya terhadap kehidupan.

Tahap kedua adalah tahap design dalam tahap ini dilakukan penyusunan materi untuk rancangan media pembelajaran geografi dan perancangan awal dalam perancangan awal ini adalah proses menyusun materi dalam aplikasi prezi mulai dari tampilan apersepsi, KI dan KD, indikator, tujuan pembelajaran, dan sub materi, gambar, video, dan soal-soal.

Tahap ketiga adalah tahap develop (pengembangan) dalam tahap ini dilakukan hasil validasi media pembelajaran geografi berbasis prezi oleh ahli materi, hasil revisi media pembelajaran geografi berbasis prezi dari ahli materi, hasil validasi media pembelajaran geografi berbasis prezi oleh ahli media, hasil revisi media pembelajaran geografi berbasis prezi dari ahli media, hasil uji kepraktisan terhadap media pembelajaran geografi berbasis prezi oleh guru dan hasil uji kepraktisan oleh siswa.

Hasil validasi media pembelajaran geografi berbasis prezi ini diperoleh dari instrumen validitas yang diisi oleh dosen sebagai ahli materi. Hasil validasi menunjukkan bahwa media pembelajaran geografi berbasis prezi sangat valid untuk digunakan dalam proses pembelajaran geografi. Media pembelajaran geografi berbasis prezi ini sangat valid digunakan dalam pembelajaran karena telah memiliki kelayakan pada komponen isi/materi, kebahasaan, penyajian, dan kegrafisan 
yang baik. Hal ini sesuai dengan teori yang dinyatakan oleh Depdiknas (2008: 28) yang menyatakan bahwa kriteria penilaian validitas sebuah media pembelajaran geografi harus mencakup Komponen evaluasi mencakup analisis isi, kebahasaan, sajian dan kegrafisan. Berdasarkan hasil yang diperoleh dari uji validitas, belum semua komponen penilaian mencapai kategori sempurna. Berdasarkan saran dan tanggapan yang diberikan oleh validator ahli materi maka dilakukan revisi terhadap media pembelajaran geografi. Revisi yang dilakukan menyangkut tampilan dari segi warna, ukuran gambar, tata tulis, menggunakan sumber yang jelas, gambar yang mendukung materi, dan tata bahasa sesuai EYD. Berdasarkan formula validasi media pembelajaran geografi berbasis prezi oleh ahli materi yang memperoleh nilai akhir 89,425\% dengan kategori valid, hal ini sesuai dengan kriteria validitas yang dimodifikasi dari Purwanto (2009:82).

Hasil validasi media pembelajaran geografi berbasis prezi ini diperoleh dari instrumen validitas oleh ahli media yang diisi oleh dosen FIP jurusan kurikulum teknologi pendidikan (KTP) dan dosen FIS jurusan geografi sebagai validator. Hasil validasi oleh validator menunjukkan bahwa media pembelajaran geografi berbasis prezi ini sangat valid untuk digunakan dalam proses pembelajaran karena pada aspek efisiensi memperoleh hasil sangat valid dan aspek tampilan program memperoleh hasil valid dan pada aspek kualitas teknis dan kefektifitasan program memperoleh hasil sangat valid. Berdasarkan formula kevalidan media pembelajaran geografi berbasis prezi oleh ahli media ini memperoleh nilai akhir 91,44\% dengan kategori sangat valid, hal ini sesuai dengan kriteria validitas yang dimodifikasi dari Purwanto (2009:82)

Hasil kepraktisan media pembelajaran geografi berbasis prezi ini diperoleh dari instrumen kepraktisan oleh praktisi yang diidi oleh dua orang guru. Hasil kepraktisan oleh praktisi menunjukkan bahwa media pembelajaran geografi berbasis prezi ini praktis untuk digunakan dalam proses pembelajaran, hal ini sesuai dengan teori yang dikemukakan oleh Mudjijo dalam Aufi Husni (2014 :86) yang menyatakan bahwa kepraktisan menunjukkan pada tingkat kemudahan penggunaan, pelaksanaan dan penafsiran hasilnya. Berdasarkan formula kepraktisan media pembelajaran geografi berbasis prezi oleh guru yaitu memperoleh nilai akhir $88,46 \%$ dengan kategori praktis, hal ini senada dengan dengan kriteria kepraktisan yang dimodifikasi dari Purwanto (2009:102-103)

Hasil kepraktisan media pembelajaran geografi berbasis prezi ini diperoleh dari instrumen kepraktisan oleh praktisi yang diisi oleh siswa. Hasil kepraktisan oleh praktisi menunjukkan media pembelajaran geografi berbasis prezi ini praktis untuk digunakan dalam proses pembelajaran, Hal ini sesuai dengan teori yang dikemukakan oleh Mudjijo dalam Aufi Husni (2014: 86) 
yang menyatakan bahwa kepraktisan menunjukkan pada tingkat kemudahan penggunaan, pelaksanaan dan penafsiran hasilnya. Berdasarkan formula kepraktisan media pembelajaran geografi berbasis prezi oleh siswa yaitu memperoleh nilai akhir $82,34 \%$ dengan kategori praktis, hal ini senada dengan kriteria kepraktisan yang dimodifikasi dari Purwanto (2009:102103).

\section{PENUTUP}

\section{Kesimpulan}

Hasil penelitian pengembangan yaitu tersusunnya media pembelajaran geografi berbasis prezi pada materi dinamika atmosfer dan dampaknya terhadap kehidupan. Penyusunan media pembelajaran geografi barbasis prezi ini sesuai dengan prosedur pengembangan 4-D yaitu: 1) pendefinisian (define), 2) perancangan (design), 3) pengembangan (develop), dan 4) penyebaran (disseminate). Penilaian produk media pembelajaran geografi berbasis prezi dilakukan oleh ahli materi, ahli media, guru mata pelajaran geografi serta siswa SMA Negeri 8 Padang kelas X IPS SI BIO 2 sebanyak 30 orang siswa.

Validasi penilaian oleh ahli materi terhadap media pembelajaran geografi berbasis prezi pada materi dinamika atmosfer dan dampaknya terhadap kehidupan berada pada kategori validdengan nilai akhir 89,425\%. Hasil penilaian dari ahli media dengan nilai akhir 91,44\% berada pada kategori sangat valid.
Penilaian kepraktisan media pembelajaran geografi berbasis prezi pada materi dinamika atmosfer dan dampaknya terhadap kehidupan dari dua orang guru geografi dengan nilai akhir $88,46 \%$ dengan kategori praktis. Untuk penilaian dari praktisi siswa dengan nilai akhir adalah 82,34\% dengan kategori praktis.

\section{SARAN}

Saran yang diberikan untuk penelitian pengembangan media pembelajaran geografi berbasis prezi pada materi dinamika atmosfer dan dampaknya terhadap kehidupan adalah sebagai berikut:

1. Pada penelitian sejenis disarankan melakukan penelitian sampai pada tahap efektifitas.

2. Guru dapat menggunakan media pembelajaran geografi berbasis prezi ini sebagai salah satu bentuk variasi dari media pembelajaran geografi yang telah digunakan dalam proses pembelajaran geografi di sekolah untuk membantu mencapai kompetensi yang diharapkan.

3. Peneliti selanjutnya dapat mengembangkan media pembelajaran geografi berbasis prezi ini dengan materi yang berbeda atau menggunakan aplikasi yang berbeda selain prezi untuk menambah pemahaman siswa terhadap materi pembelajaran geografi. 


\section{DAFTAR PUSTAKA}

Anggraini, Ika. 2011. Pengembangan Handout Yang Dilengkapi Dengan Konsep Utama Disertai Mind Map Pada Materi Struktur Dan Fungsi Jaringan Tumbuhan Untuk SMA Kelas XI Semester 1 Sesuai Dengan Kurikilum KTSP. Skripsi: Padang

Arsyad, Azhar. 2010. Media Pembelajaran. Jakarta: Pt RajaGrafindo Persada

Husni, Aufi. 2014. Pembuatan Media pembelajaran geografi Fisika Berbasis Ict Mengintegrasikan Mstbk Pada Materi Mekanika Klasik Sistem Kontinu Untuk Mencapai Kompetensi Siswa Sma Kelas Xi. Padang: Skripsi

Nofrion, N. 2018. Effectiveness of EXO OLO TASK Learning Model Based on Lesson Study in Geography Learning. IOP Conf. Series: Earth and Environmental Science 145 (2018) 012038 doi :10.1088/1755$1315 / 145 / 1 / 012038$

Nofrion. 2017. Peningkatan Aktivitas Belajar Siswa Melalui Penerapan Metode Jumping Task pada Pembelajaran Geografi. E_Journal Geografi UNIMED.Volume 9, Nomor 1 tahun 2017. Hal 11-20.

Purwanto, Ngalim. 2009. Prinsip-Prinsip Dan Teknik Evaluasi Pengajaran. Bandung : Remaja Rosdakarya.

Putra Sairi, Andi. 2011. Pengembangan Media Pembelajaran Fisika Interaktif Berbasis Flash dengan Pendekatan SAVI Pada Pokok Bahasan Impuls dan Momentum Di
Kelas XI SMA 3 Pariaman. Padang:Skripsi

Putra, Nusa. 2011. Research \& Development Penelitian dan Pengembangan: Suatu Pengantar. Jakarta: Rajawali Pers.

Setyosari, Punaji. 2010. Metode Penelitian Pendidikan dan Pengembangan. Prenada Media Group. Jakarta

Sugiono. 2009. Metode Penelitian Pendidikan: Pendekatan Kuantitatif, Kualitatif, dan $R \& D$. Bandung: Alfabeta

Supriadi, Aris. 2011. Peningkatan Hasil Belajar Geografi Materi Atmosfer dengan Menggunakan Aplikasi Media Pembelajaran Digital (Mpd) Bagi Siswa Kelas X.2 Sma Negeri I Grobogan Pada Semester 2 Tahun 2009-2010. Jurnal (online)

Trianto. 2010. Mendesain model pembelajaran inovatif progresif: kondep,landasan dan implementasinya pada kurikulum tingkat satuan pendidikan. Jakarta: kencana 